\title{
"Through the Land of Nod and Wink": Representations of Ireland in The Twelfth of Never by Ciaran Carson
}

\author{
Elisabeth Delattre \\ Université d'Artois, France
}

Copyright (c) 2013 by Elisabeth Delattre. This text may be archived and redistributed both in electronic form and in hard copy, provided that the author and journal are properly cited and no fee is charged for access.

\begin{abstract}
The Twelfth of Never, published in 1998 by Ciaran Carson, is composed of seventy-seven poems in the form of the French sonnet. This collection embodies the poet's ever-recurring preoccupations with the representation of the world, both past and present, through the medium of language. This article aims at showing in what ways reality is transfigured and re-created for the reader. The poet turns to a form of writing in motion that subverts tradition and provides the means of entering another world, that of fantasy.
\end{abstract}

Key Words. Sonnet, representation, metaphors, reality, fantasy.

Resumen. El volumen The Twelfth of Never, que Ciaran Carson publicó en 1998, contiene setenta y siete poemas escritos en forma de soneto francés. La colección recoge las preocupaciones recurrentes del poeta en torno a la representación del mundo, tanto pasado como presente, a través del lenguaje. El propósito de este artículo es mostrar los modos en que el autor transfigura y recrea la realidad, recurriendo para ello a una forma de escritura en movimiento que subvierte la tradición y proporciona maneras de penetrar otro mundo, el de la fantasía.

Palabras clave. Soneto, representación, metáforas, realidad, fantasía.

Alternative universes loom before us with their many shadows (Ciaran Carson, Last Night's Fun)

Ciaran Carson's career as a poet, prose-writer and translator was acknowledged in 2011 when he was conferred the honorary degree of Doctor of Literature by University College Dublin. In his address, Professor Frank McGuinness defined him as "one of the most fertile imaginations and intrepid intellects revelling in the English language over the past forty years". Indeed, although he has been the recipient of many awards, Carson's work has often daunted critics who have at times felt baffled by the breadth of reference or by the difficulty of fitting him into pre-defined categories or genres. As Neal Alexander wrote in the introduction to the first full-length study of the Northern Irish writer: "Experimental rather than self-consciously avant-garde, Carson's poetry exhibits a remarkable linguistic inventiveness, formal complexity, and intellectual daring" (Alexander 2010: 1).

In The Twelfth of Never, published in 1998 and reproduced in Collected Poems ten years later, Ciaran Carson gives us a vision at times cruel, ferocious or nostalgic and lyric, even humorous of Ireland, "a fantasy Ireland" (Smith 2009: 115), in which the word "liberty" is determinant. The past - not only the Irish conflicts, but also the First World War, the

ISSN 1699-311X 
Napoleonic wars, the French revolution -, the myths and traditions, as well as the great literary models - Keats, Kavanagh, among others -, are revisited. This leads to the singular (re)composition of a country seen from the inside, with very few precise geographical references - at best a dozen - so as to give it a dream-like quality, but also seen from the outside, since a few poems include the poet's visit to Japan. The Twelfth of Never thus appears as a fragmented text, discontinuous and repetitive, yet none of its seventy-seven parts can be separated from the whole.

As Carson declared in an interview in September 2000, "the experience of a poem should be that: "awkward, anxious, strange, new. [...] It's no fun if you already know the answers; it is fun when you are disturbed" (Brown 2002: 143). Words become objects of re-presentation, "style per se" being "a thing to aim at" (Brown 2002: 145). In other words, the kaleidoscopic representation of Ireland is reflected at the level of language, itself subject to every mutation and uncertainty, as the poet writes in the last poem "Envoy": "For there are many shades of pigment in the spectrum, / And the printed news is always unreliable" (Carson 1998: 89).

As Carson himself acknowledged, the influence of James Joyce can be felt in this work, notably that of the technique used in the latter part of Ulysses, which David Butler has analysed at length: "the collection adopts many of the strategies developed therein by Joyce, notably in relation to the fragmentation and distortion of the popular ballad" (Butler 2003: 337). However, Joyce may not be the only dominant influence and that of traditional Irish music is probably even more important, "with songs and musical allusions frequently a feature of his poems", as Sean Crosson has noted (Crosson 2004: 61). The influence of music will play an increasing part in Carson's work, especially in his later collections of poems, For All We Know (2008), On the Night Watch (2009), or Until Before After (2010). More generally, to quote Neal Alexander, The Twelfth of Never appears as

a hallucinatory sonnet sequence, switching rapidly between different places and times, and marshalling a bewildering cast of historical places and mythological characters, the book blends history, memory, and surreal fantasy in a concerted scrambling of Ireland's sectarian iconographies (Alexander 2011: 9).

This article will focus on the concept of representation. It aims at showing how the reflection on reference, which is the driving thread of poetic vision and writing in The Twelfth of Never, leads the reader to effect a kind of reverse journey. Starting from a conventional mode of representation, involving a return to inherited poetic codes - here the form of the sonnet -, the author turns to a form of writing in motion. The reference to reality is situated in a cluster of references to an aesthetic which is itself subject to reappraisal.

\section{A subversive outlook}

The Twelfth of Never is made up of seventyseven sequences of fourteen alexandrines each, cut up into two quatrains of enclosed or embraced rimes followed by two tercets actually forming a sextet. Carson has used the form of the French sonnet which is composed of twelve decasyllables, instead of iambic pentameters as in the Shakespearean sonnet. The two quatrains and the two tercets are separated by an interval on the page, contrary to English habits. One might see in this a subversive attitude, that of an irreverent son towards English tradition, feeling affinities with the revolutionary ideas promoted by French symbolists who were fans of liberty. Significantly, in The Alexandrine Plan, also published in 1998, Carson translated thirty-four sonnets from three great French symbolist poets of the nineteenth century: Baudelaire, Rimbaud and Mallarmé. In many ways, this collection can be seen as complementary to The Twelfth of Never. Carson's interest in Arthur Rimbaud showed again in his "translation", or rather adaptation and even "renovation" of twentyfive of the French poet's prose poems, Illuminations, which he published under the title In the Light of in 2012.

In fact, as often, Carson plays with poetic rules: "You need the rules to create wit, skill, humour, irony, play. You play with the rules, and within the rules; sometimes even against the rules. You play your own game" (Brown 2002: 149). The epigraph to The Twelfth of Never indicates the aesthetic choices of the author and the codes of reference of the work. The definition of "St Tib's Eve" drawn from the dictionary of phrases and fables, signals 
that one is entering the domain of the unreal, of pure imagination, since this feast does not exist in the calendar. The term "Greek Calends" then evokes the title of the book, "The Twelfth of Never", which is a polysemic term suggesting the Orange marches of the $12^{\text {th }}$ of July, as well as an idealised world. Besides, as usual with Carson, there is a form of intra-textuality as this expression already appeared twice in the sequence of poems "Letters from the Alphabet" included in Opera Et Cetera published in 1996. At the letter "T", the author related his first experiments with tobacco and nicotine: "You remember $[. .$.$] . The silly names we gave each$ other? / No? 'The Twelfth of Never'?” (30) At the letter " $Z$ ", the poet turned postman conveyed a timeless message: "In the morning, you will open up the envelope. You will get whatever / Message is inside. It is for all time. Its postmark is 'The Twelfth of Never'" (6).

To such polysemy is added a form of destructuring since, without any apparent order, some sonnets evoke the past, the struggles of his country for freedom while others conjure up Celtic legends, the wars of the Napoleonic period or else the First World War. Contemporary events are also mentioned, thus the ceremonies and other inaugurations, with the presence, in a somewhat humorous way, of the then President of the Irish Republic, as in the sonnet "1998":

In this ceremony, the President will eat the host,

Which represents the transubstantiated moon.

Then Her Nibs'll christen the Monfgolfier balloon:

Traditionally, it's always called The Holy Ghost.

[...]

Already, you've partaken of our President.

You ate her bread. You licked her salt. You

drank her drink. (Carson 1998: 40)

More generally, Carson submits Irish icons and mythical, religious or literary traditions to an ironic re-evaluation, amplified by this unusual poetic use of alexandrines, as in this extract from the sonnet "Lord Gregory".

It's that dewy blue of your mantle, Mavourneen,

Cobalt banner of the yet-to-be republic

Which enraptures us, as numerous as the grass is green:

We are your unseen agents, growing thin and thick

In every patch of field, and briar, and the mireland.
Creeping through the thistled fields, we are the weed,

That disrespected emblem of old Ireland.

(Carson 1998: 47)

The end result is to create a somewhat debunking perspective, in the context of what the poet names "the imminent republic of the future" (21). Likewise, Carson's version of a famous poem by Kavanagh, "Spraying the Potatoes", makes use of the images of Kavanagh's poem but transforms the pastoral tone into a political atrocity with the image of a Derry rebel hanged by fourteen British soldiers in red uniforms:

I watched him swing in his Derry green for hours and hours,

His popping eyes of apoplectic liberty

That blindly scanned the blue and white potato flowers.

(Carson 1998: 85)

Elsewhere Carson juxtaposes a poem, "Twelfth Day", which questions the effects of the Orangemen's celebrations, with another poem entitled "The Ay O'Haitch", which illustrates the way Catholics, during their yearly march, re-create and perpetuate the sectarian divisions generated by the Protestant marches: "We will outbreed the others; we have done our sums. / Will you, Sir, join our Union of Hibernians?" (Carson 1998: 58) Moreover, the narrator often seems to be unaware of what he himself declares and is quite puzzled in front of the events that the protagonists have to undergo; in the poem "Manifest", he is summoned before the captain of the ghostly galleon in order to account for his acts:

He asked me plain, what I had thought or done or said

To make Old Ireland free, or had I fought at Waterloo?

I had no answer for him. He chopped off my head.

(Carson 1998: 63)

Ireland is also seen from the outside, and in a humorous way too, in the sonnets where the poet relates his stay in Japan, seen as a kind of flight, of desertion. But the call of the motherland is soon felt, since the Japanese language and culture remain entities which are quite hard to understand and decipher, as in the sonnet "Green Tea": 
The writing everywhere on walls illegible to me.

The faces in the crowds unrecognisable.

The labyrinth to which I hadn't got the key.

Investing in the Zen is inadvisable.

(Carson 1998: 22)

Only by meeting other compatriots in the bars of Tokyo can exile be made more bearable, and the atmosphere of the native country is re-created, as is shown in the conclusion to the sonnet "February Fourteen": "Fourteen Bloody Marys later you lisped of home. / We then discovered we had come from different schools, / Yet thought the same, like mutants of one chromosome" (Carson 1998: 75).

Carson builds his work from a network of intertextual echoes that constitute the background to the referent, but that also allow for a critical review of representative codes. Adding a bibliography at the end of the book indicates the debts of the author in the fields of history, haiku poetry or traditional Irish music, and forms a sort of "survey of the author's icons" (Compagnon 1979: 333). In short, writing would be an endless beginning, as well as a form of reappraisal. The intertextual presence of John Keats's poetry is a means for the poet to revisit his model in a somewhat irreverent mood. This is what we can read in the sonnet "Fear" which takes up Keats's sonnet "When I have fears that I may cease to be"; the non-sequitur and the device of repetition - the expression "I fear" recurring at the beginning of each verse -, is a source of comic, and contributes to turn upside down the anxious tone of Keats's poem:

I fear the vast dimensions of eternity.

I fear the gap between the platform and the train.

I fear the onset of a murderous campaign.

I fear the palpitations caused by too much tea. (Carson 1998: 65)

Furthermore, the sonnet "The Arterial Route" is a pastiche of the ballad "La Belle Dame Sans Merci," revised and condensed in the Japanese manner. Sure enough, Carson acknowledges his debt to Keats's poetry but at the same time he subverts it from the inside and presents the reader with another world, maybe more real, more authentic, which is to be found in writing

1. "relevé des icônes de l'auteur" (translation mine, as well as for all subsequent translations from the French). itself, in poetic language. This is what he declared: "I love Keats. The world of the Odes is made "real' in language. Is it the real world?" (Brown 2002: 144).

The study of reality in The Twelfth of Never, that of the Ireland of yesterday, today and tomorrow, cannot be dissociated from the study of the formal codes forming the backbone of the poems. Yet at the same time the references to the outside of the text, i.e. literature, the past, legends, this constant and rapid interchange between the different worlds create a kind of maelstrom which baffles the reader so that dream and reality get blurred, as we can read in the very first sonnet "Tib's eve": "This is the land of the green rose and the lion lily" (Carson 2002: 13). That is probably why the poet seems to wink at the reader in "Milk of Paradise", a sonnet in which he conjures up De Quincey and Coleridge in a humorous way, caricaturing the narrator of The Confessions of an Opium Eater:

And this is why you must beware my flashing eyes,

My floating hair, my pupils black as creosote,

With which I saw through Doctor Ecstasy's disguise.

(Carson 1998:52)

Against the background of a subversively normative structure, setting literary codes at variance, there appears a new economy of representation, which gives rise to a redefinition of the relation between writing and the world.

\section{A "deteriorating mirror"}

The reality conjured up by The Twelfth of Never is excessive. The tragic, violent battles with their retinue of victims and sufferings pervade Caron's poetic discourse. The memory of the difficulties encountered by Napoleon's Great Army in the sonnet "Banners" is an example among others:

For all that died from shot and sword, more died of disease:

Plagues, dysentery, miasmas, suppurating grot

Beyond the non-existent doctors' expertise.

Some were given military burials, others not.

(Carson 1998: 84)

Indeed such a background is but a pretext; Ireland is never forgotten, and the poet compares this tragedy to that of his country victimized by the Great Famine: "And for a 
moment I thought of dear old Ireland: / Fields of corpses plentiful as dug potatoes" (Carson 1998:84). It seems as if History and its tragedies are a never-ending repetition as the poet will regularly recall in his work, and more particularly perhaps in Breaking News published in 2003, which draws upon the writings of the $19^{\text {th }}$ century Anglo-Irish war correspondent, William Howard Russell.

Elsewhere in The Twelfth of Never, the historical context is seen from unexpected or somewhat baffling angles. Thus the title of the sonnet "The Year of the French" (Carson 1998: 82) does not refer to the unsuccessful landing of the French in Ireland in 1798 , or to the French revolution (itself the subject of the sonnet "The Rising of the Moon" [Carson 1998: 19]), but to the forced stay of the Napoleonic army in Egypt. The future there is depicted as black as the "Rosetta stone" (Carson 1998: 83). Likewise, it is Papists who, quite incongruously, read a "Riot Act" from A to $\mathrm{Z}$ to the so-called "loyal" narrator in the sonnet "The Lily Rally". The different historical perspectives have an emblematic function, yet disruptions occur in the very midst of representation. The metonymic presence of the individual being within history becomes that of a derisory object, a mere "puppet". The narrator, together with Ireland, are, for their own part, the fragmented mirror of a reality with puzzling facets, or rather "the deteriorating mirror" on the wardrobe door from which one of the legendary elves steps out, and there is no longer any consistency to the words. Framing words becomes utterly impossible:

I got that story from the Pooka, who appeared

To me last night. He stepped out from the wardrobe door,

Shimmering in its deteriorating mirror,

Shivering the fringes of his ectoplasmic beard.

I saw my breath as visible to him as nebulae

Of chalky sentences he'd drawn with a hook

From deep within me. Then he read me like a book.

I tried to speak, but there was nothing I could say.

(Carson 1998: 64)

This image will significantly reappear in a work of fiction, Exchange Place, part thriller, part spy novel, published in 2012. When the narrator enters the studio once occupied by a vanished friend, he finds himself confronted by "the familiar chaos dimly reflected in the deteriorating mirror" (Carson 2012a: 159).

Against a revisited intertextual background, Carson questions the powers of language and poetic discourse, the relationship entertained by the latter with the outside of the text: "Metamorphoses of martial words we speak", as he writes in "The Legions of the Dead" (Carson 1998: 83). The accumulation of concrete details confines to parataxis and the listing of miscellaneous objects symbolises the routing of those armies, but also the chaos and disorder of the surrounding world. The numerous concrete details contribute to propping up the text, but their excess nevertheless produces in return an effect of saturation that shifts the meaning of the words. An example of such semantic excess would be the whole sonnet "Found" which is a catalogue, an inventory in the style of the $20^{\text {th }}$ century French poet Jacques Prévert, of objects found in a stranded Spanish galleon.

To the apparently arbitrary juxtaposition of subjects is added an interweaving of the threads of time, which blur the course of the poetic narration. With its discontinuous narration, composed of fragments from the past and the present, The Twelfth of Never is a degraded mirror, whose every part would reflect, like the drawings of a kaleidoscope, the fundamental and paradoxical unity. The most frequent tense used is that of a non temporal, magnetic preterit that inveigles and baffles the reader. Gaps occur in the continuum of the story when the poet resorts to the present tense. The pyramid of the past is thus destabilised and fractured against the foreground of the present. Stories and legends overlap, the immediate and the remote future get blurred ("the imminent republic of the future" [Carson 1998: 21]), the discourse turns back on itself only to hide its gaps as it were. There arises an incessant interchange between the past and the present, a transit system that often annihilates the perspective and folds up the layer of the past over the fragile present or a hypothetical future. The logic of time is defeated by that of the words, in which concepts and ideas converge so as to diverge all the better. The resurgences of the present underline the precariousness of syntactical references, the elusive character of temporal data. The "here and now" of the sonnet "Banana Tree" might have served to 
anchor the narration but it is not made use of: "The President divests herself of here and now // And transubstantiates herself into a swan" (Carson 1998:70). The beings, like representation, can only be perceived when they vanish or disappear incongruously or violently, just like the Irish rebels in "Spenser's Ireland":

At the drop of a hat they are wont to vanish Into deep dark woods. Forever on the make,

They drink and talk too much. Not all of it is gibberish.

(Carson 1998: 72)

In The Twelfth of Never, certain recurring terms turn into metaphorical motives which enable reality to appear under a new light and thus unveil the functioning of the text. The cohesiveness of the book rests upon a network of factual repetitions that contribute to the foliated structure of the poems.

\section{Metaphors and repetitions or the metamor- phosis of reality}

Repetitions forming links occur from poem to poem. Thus the poem "The Tobacco and Salt Museum" starts with this line: "The Professor drove me into smoggy Tokyo" (Carson 1998:15), taken up a few pages later at the beginning of the sonnet "The Rising Sun": "As I was driven into smoky Tokyo" (Carson 1998: 20). Of course the repetitions are not always so obvious. Rather than repetitions one should talk at times of furtive echoes, as with the pockmarked soldiers in a poem relating a ceremony in honour of those dead in action, who appear in negative against the image of the omnipresent "pockmarked moon" about fifteen poems later, in a supernatural context this time. The link is also at times quite obvious, thus in the sonnet "The Wind that Shakes the Barley" (Carson 1998: 32), the phrase "the Tailor's Twist" at the end of the penultimate line becomes the very title of the following sonnet. The poetic text is composed of a host of factual repetitions. These contribute to stratify it and form a labyrinthine series of degraded mirrors. Resulting from the fragmentation of the poetic narration, they are the signs of an unravelling of the vision comparable to the falling apart and dismemberment of the bodies, symbolised by the recurrence of such terms as "disembodied", or "headless", and caused to some extent by the power of different plants, hallucinogenic or not that sprinkle the discourse.

Whereas such fragmentation had led, as we saw earlier, to the dissolution of the being and reality, the repetitions give movement to the writing, which is amplified by a series of metaphors. Such metaphorical paradigms ultimately confer to the world some other cohesion, drawn from the origins of the poetic vision and imagination. As Carson declared in September 2000: "I believe that the world exists in such a way that everything relates to something else. Or we make it exist in that way, making links all the time, connecting things up, one thing always leading to another" (Brown 2002: 142). In this view, the number seven, which is representative of the universe in motion in its entirety, is significant by its recurrence: "For everything can be contained in anything" as he writes at the incipit of the sonnet "Mountain Dew" (Carson 1998:42).

More significant still, the play on colours is predominant and these involve a whole set of peculiar vibrations. They even constitute an object of fascination for the poet. Four colours dominate this poetic universe: "green" of course in reference to Erin, the isle of the blessed in the Celtic world; "blue", a symbol both of the Republic, and of the unreal, of dreams, of this passage to the other side of the mirror; "white" which designates purity, rebirth, life, with the recurring presence of the "cherry blossom" or the "whitethorn", as well as the cold of death with the omnipresent symbol of the snow, a possible (or probable?) intertextual reference to James Joyce's Dubliners, in which society is stifled under its weight, "faintly" falling "upon the living and the dead" (Joyce 1967: 220). The following extract from the sonnet "The Londonderry Air", with its deep melancholy, is significant in this respect:

Snow falls eternally within my souvenir Of him, who wore the suit of Lincoln corduroy. He was my noble pikeman, and my pioneer; Snow falls eternally upon my Danny Boy.

(Carson 1998: 60)

Contrary-wise and complementarily, "red" is represented by the sun but above all the poppy, "the emblem of Peace and the Opium Wars" in "The Poppy Battle" (Carson 1998:14), as well as "the emblem of Death and the Special Powers" in "Salt of the Earth" (Carson 998:17). 
This is where the ambivalence and duality of Carson's thought are to be found. Doubt and uncertainty concerning the future of his country appear at regular intervals. Nothing is solved, the future remains uncertain, as the narrator understates when addressing a ghostly audience: "You know, our two states could stand in each other's stead. / Excuse me, Sir, I am sorry for your troubles" in the sonnet "The Ambassadors" (Carson 1998: 87). The text does not progress, it turns back on itself. As with history, writing goes forward by stepping backwards: "The campaigns included many oxymorons. I You want to know how many yards we gained? Don't ask" (Carson 1998: 69). This is the conclusion to a poem entitled "Mustard" in reference this time to World War One.

If, according to Paul Ricoeur, using metaphors means "a shift through some literal sense"" (239), then language is well and truly a passage, an inbetween space. As a symbol of such a passage, of this transitory state between life and death, the moon is another constant element of a poetry pervaded by its cold luminescence. This is the domain of dreams and the unconscious, imagination and magic in which all kinds of metamorphoses are possible, as in this extract from "Catmint Tea": "Our wild imaginations started to take wing. [...] Then he became the man and I became the cat" (Carson 1998: 34). The main characteristic of such metaphors, which evolve as the text progresses, is metamorphosis. They weave over the meanderings or fractures of the text a consistent web, symbolised by the weave of the cloth which is that of the narration: "The knotted cord is implicated in the plot", as we learn in the "Mountain Dew" (Carson 1998: 42). Indeed, such coherence born from writing gives shape to things and events and tames their violence.

\section{Overture and circularity}

In the end, the complex deconstruction, or still the de-multiplied representation to which Carson resorts, appears as a subversive aesthetic. One can feel a form of doubt and uncertainty seep between the lines: "YYou seem [...] to have a problem with the language", declares Hibernia when accusing the poet of

2. “parler par métaphore, c'est dire quelque chose à travers quelque sens littéral." being a renegade interpret in the sonnet "The Display Case" (Carson 1998:74). Turning paradox into a principle, the poet sets his own logic at defiance and it is at this very moment of imbalance that the work reaches a form of completeness: "You'll find that everything is slightly out of synch," as we can read in the last poem "Envoy" (Carson 1998: 89), where the poet takes leave of his reader, a poem which reaches back to the first sonnet "Tib's Eve", thus forming a kind of loop or infinite recurring, as in an Irish dance.

The unstable character of language ("dodgy", or "dodginess" thanks to which "the essence of things can cross space and time" [Brown 2002: 151]) - which is a reflection of life and matter the uncertainties of time and space, the play with the past and the present break up the vehicular and referential function of the words. Owing to this dramatisation of the discourse or its neutralisation, the referent becomes annihilated by the dynamics or vacancy of language. The poetic texts build themselves around this absence, the void created by such inaccessible reference: "The only freedom that you'll find is in the dead domain", such is the conclusion to the sonnet "Dark Rosaleen" (Carson 1998:31).

As he writes in the foreword, Carson's poetry is directly inspired from the haiku, which is a classical Japanese poem of three lines, the first and the third of which are pentameters, and the second is a heptameter. The use of the haiku is not a new practice with Carson, since it already featured in Belfast Confetti, first published in 1989. "The number of their syllables was seventeen", as one is reminded in the sonnet "The Rising Sun" (Carson 1998: 20). Elsewhere in The Twelfth of Never, haiku extracts are reproduced verbatim through the process of collage, as is the case in the sonnet "Banana Tree" which ends with these lines: "Full moon: a walk around the pond; the night is gone" (Carson 1998:70). The haiku extracts - as in Carson's previous work, Belfast Confetti (1987) -, are taken from, or inspired by the Japanese poet Bashộ, a comment made by the poet himself in his "Acknowledgements". Instead of trying to hide the arbitrariness of the sign, the haiku foregrounds the symbol and becomes a kind of minimalist drawing. There is with Carson a will to recover spontaneity, the immediacy within 
the word itself but the word, "by its very nature abolishes its immediacy, right from the start"3 (Bonnefoy 1990: 142). In such a practice, language finds in its own silence the impulse of its own power.

Paradoxically, but in fact again in a complementary way, the other favourite domain of the poet, that of traditional Irish song leads us to see this poetry as a form of oral discourse, in the tradition of the minstrels. In The Twelfth of Never many poems bear titles of ballads, reels, gigs and other planxties from traditional Irish music, which serve as referents, or even labels. This is what the poet wrote in Last Night's Fun published in 1996: "So, the names of tunes are not the tunes: they are tags, referents, snippets of speech which find themselves attached to musical encounters" (Carson 1997: 7). Such music is characterised, according to Carson, by an "endless variety within a fixed framework" (28). Poetic art consists for the writer in assuming such instantaneity, in integrating it into the form of his own discourse. Indeed, Ciaran Carson's poetry rests upon a subtle game of recurrences. These weave threads within the discourse that, by multiplying, crossing over, give birth to another discourse, which the reader interprets in his or her own manner. As Paul Zumthor writes, "this outlook which 'the oralist' tries to extract from the continuousness of reality consists in discourses rather than texts, situational messages and not finite enunciations, impulses rather than stases" (126). ${ }^{4}$ Poetic art consists for the writer in assuming such instantaneity, integrating it into the form of his discourse. Ciaran Carson's poetry rests upon this subtle play on recurrences. These "weave within the discourse associative threads that, by dint of being multiplied, interwoven, beget another discourse, operating with elements from the former as would occur in a dream in the case of wakened experience, to the benefit of phantasms expressed by the poet" but which the reader interprets and makes his own. Each

\section{3. "par nature [en] abolit, d'entrée de jeu l'immédiat."}

4. 'ce regard que 'l'oraliste' cherche à découper dans la continuité du réel, ce sont des discours plutôt que des textes, des messages en situation et non des énoncés finis, des pulsions plutôt que des stases ." of the nuances thus produced and "received as new information, increases the knowledge to which such a voice invites us" (142). ${ }^{5}$

In The Twelfth of Never, there are at the same time the most extreme forms of liberty and constraint. The overture of the form is obtained, not by leaving it to chance, but by delivering the material of the language in its flexibility. I would contend that such a work rests upon a principle of "construction-destruction", which is to be found in the twelve-toned contemporary music, also called serial music, of such composers as Alban Berg or Pierre Boulez. There occurs within the series which are at the basis of the composition a form of dislocation of the elements through progressive transformations that disrupt the logic of the sequences of do-decasyllabic verses. The development of this destruction leads to the "circumscription of an aleatory sphere, as the culminating point of destructive tendencies" 6 (Bosseur 1993: 71), of which the sonnet entitled "Con Script", written in two separate words, is emblematic. It starts and ends in this way:

Had I all the money that I left in your store, Hard-hearted landlady, I'd not bide here tonight, But I'd ride on my horse in the silvery light, And buy myself an élite military corps.

[...]

'Give me six Irishmen like me, and we will make

A constellation pointing at the Northern Star; Our swords of light will ravage Ulster, for your sake.'

(Carson 1998: 67)

In this defiant poem invoking the Queen ("Her Majesty"), the poet in the garb of a soldier at her service, offers to bring chaos and annihilation to his native country, as a prelude, maybe to the birth of a new world.

5. "tissent dans le discours des fils associatifs qui, multipliés, entrecroisés, y engendrent un autre discours, opérant avec les éléments du premier comme fait le rêve avec des fragments d'expérience éveillée, au profit de fantasmes exprimés par le poète $[. .$.$] , reçue comme une information nouvelle,$ accroît la connaissance à laquelle nous invite cette voix."

6. "circonscription d'une sphère aléatoire, point culminant des tendances destructrices." 


\section{Conclusion}

As Carson wrote in Fishing for Amber, a book in prose published in 1999, which is subtitled "a long story" but actually composed of seven stories told in seven days by a fictitious character who himself appears in a story told by the writer's father: "narrative [...] is possible only because we make factitious links between one instant and the next: blinks of the eyelid, adumbrated by the ghosts of things already swallowed by the void" (Carson 1999: 345). The mechanism of knowledge is thus of a cinematographic nature, every motion is an illusion for the poet, as a disciple of Zeno, who remembered with delight the sleight of hand executed by his father during his childhood by means of the "flicker-book". Quite significantly, Carson's reflections in the Author's Note about Rimbaud's prose poems whose "translation" he published thirteen years later, seem to echo the previous quotation, and might also apply to The Twelfth of Never: "the poems flit within the inward eye like brightly coloured magic lanterns, pictures from a marvellous book, visions of another world, scenes from an avant-garde film" (Carson 2012: 12).

By deconstructing, fragmenting the lived real and the imagined unreal, by creating this incessant and rapid back and forth movement, there occurs within the reader's imagination a kaleidoscopic vision which is perhaps more real and fixed than reality, yet is at the same time brutal, lyrical and ironical, and whose singularity cannot but fascinate. In The Twelfth of Never, the reader has entered another world, a strange, disturbing one where the answers are still to be found, while waiting, as the poet writes in the last stanza of "Envoy", for the doors of Paradise to open...

\section{Works Cited}

Alexander, Neal. 2010. Ciaran Carson. Space, Place, Writing. Liverpool: Liverpool U.P.

Bonnefoy, Yves. 1990. Entretiens sur la poésie (1972-1990). Paris: Mercure de France.

Bosseur, Dominique \& Jean-Yves. 1993. Révolutions musicales. La musique contemporaine depuis 1945. Paris: Minerve.

Brown, John (ed.). 2002. In the Chair: Interviews with Poets from the North of Ireland. The Cliffs of Moher: Salmon Publishing.

Butler, David. 2003. "'Slightly out of synch': Joycean Strategies in Ciaran Carson's The Twelfth of Never”. The Irish University Review: vol. $33 \mathrm{n}^{\circ} 2$, pp. 337-55.

Carson, Ciaran. 1989. Belfast Confetti. Loughcrew: Gallery Press. 1996. Opera Et Cetera. Loughcrew: Gallery Press.

1997 (1996). Last Night's Fun. London: Pimlico edition.

1998. The Twelfth of Never. Loughcrew: Gallery Press.

1998a. The Alexandrine Plan. Loughcrew: Gallery Press.

1999. Fishing for Amber. London: Granta Books.

2003. Breaking News. Loughcrew: Gallery Press.

2008. Collected Poems. Loughcrew: Gallery Press.

2008. For All We Know. Loughcrew: Gallery Press.

2009. On the Night Watch. Loughcrew: Gallery Press.

2010. Until Before After. Loughcrew: Gallery Press.

2012. In the Light of. Loughcrew: Gallery Press.

2012a. Exchange Place. Belfast : Blackstaff Press.

Compagnon, Antoine. 1979. La Seconde main ou le travail de la citation. Paris: Seuil.

Crosson, Sean. 2004. "Performance and Music in the Poetry of Ciaran Carson", Nordic Irish Studies, Special Issue: Contemporary Irish Poetry, $\mathrm{Vol} 3, \mathrm{n}^{\circ} 1$.

2008. 'The Given Note': Traditional Music and Modern Irish Poetry. Newcastle: Cambridge Scholars Publishing. 
Joyce, James. 1967 (1914). Dubliners. Harmondsworth: Penguin. 1969 (1922). Ulysses. Harmondsworth: Penguin.

Kavanagh, Patrick. 2004. Complete Poems. London, Allen Lane: Penguin.

Keats, John. 1987. The Complete Poems. Harmondsworth: Penguin Classics.

Ricoeur, Paul. 1975. La Métaphore vive. Paris: Seuil.

Smith, Stan. 2009. “Cruising to the podes': Ciaran Carson's virtual realities.” in Kennedy-Andrews, Elmer (ed.). Ciaran Carson. Critical Essays. Dublin: Four Courts Press.

Zumthor, Paul. 1983. Introduction à la poésie orale. Paris: Seuil.

Received 6th August 2012 Final version 28th December 2012

Elisabeth Delattre holds a $\mathrm{PhD}$ on the work of the Anglo-Irish novelist, J.G.Farrell. She has published a number of articles in Etudes Irlandaises and various other journals and collective works. She specialises in contemporary Irish literature, including Derek Mahon, Ciaran Carson, J.G.Farrell and Michael Longley. She teaches at the Université d'Artois in Arras, France, and is also a research associate with the Centre for Irish Studies at the University of Lille. 